\title{
PROXIMITY AS A KEY FACTOR TO NARROW THE RELATIONSHIP BETWEEN SUPPLIER AND ITS CUSTOMER - A CASE STUDY IN THE AUTO INDUSTRY
}

\author{
Fabio Yukio Takeno \\ Universidade Nove de Julho, Brazil \\ E-mail: ftakeno82@gmail.com \\ Wagner Cezar Lucato \\ Universidade Nove de Julho, Brazil \\ E-mail: wlucato@uninove.br \\ Rosangela Maria Vanalle \\ Universidade Nove de Julho, Brazil \\ E-mail: rvanalle@uninove.br \\ Milton Vieira Júnior \\ Universidade Nove de Julho, Brazil \\ E-mail: mvieirajr@uninove.br
}

Submission: 03/06/2015

Revision: 15/06/2015

Accept: 08/07/2015

\section{ABSTRACT}

The modern literature shows that the Just in Time (JIT) utilization in the relationship between client and its supplier aims at optimizing the flow in the supply chain. Nevertheless, there are other aspects to be considered for the full utilization of the lean supply practices. Among those, the proximity tries to improve the liaison between the client and its provider of materials and components as a possible response to an increasing competitiveness level. To explore this subject this work had the objective of evaluating the determinant factors that could possibly explain the partial relocation of a manufacturing facility to create proximity conditions with one of its clients. For that purpose, a case study was developed in which a Brazilian auto parts manufacturing company belonging to the first tier of the automotive supply chain was considered. Because of such study, it was possible to conclude that the strategic advantages resulting from the proximity overpassed the 
INDEPENDENT JOURNAL OF MANAGEMENT \& PRODUCTION (IJM\&P)

http://www.ijmp.jor.br

v. 6, n. 4, October - December 2015

ISSN: 2236-269X

DOI: 10.14807/ijmp.v6i4.341

conventional reasoning of considering financial gains as a key factor to justify such a decision. In fact, the cost savings obtained with the plant relocation were not enough to justify the investment made.

Keywords: JIT, proximity, lean supply, automotive industry, autoparts manufacturing, lean logistics

\section{INTRODUCTION}

Despite the utilization of Just-In-Time (JIT) in the relationship between customer and suppliers to optimize the supply chain flow, there are some aspects that need to be considered for a robust utilization of the lean logistics. Opposing what was presented by Rego and Mesquita (2011) in relation to the inventory management for the automotive aftermarket, the supply of parts for the automakers requires higher levels of quality and management. Besides, the life cycle of those products can be forecast, not requiring higher time buckets and involving very low risk of production interruption due to obsolescence (PACHECO et al. 2012). These principles allied to the supplier proximity improve significantly the relationship with potential customers, as a way to respond to increasing competitiveness levels resulting from the international trade integration (AYMARD; BRITO, 2009). In this context, the geographical distances and a better potential localization define a slim line between the minimum cost of a new plant and a maximum service level to the customer (BENNET; KLUG, 2009; LEE; LEE, 2011). This particular point should be analyzed as part of the lean supply.

In recent years the restructuring of the automotive supply chain has been widely explored in the literature (GUARNIERI; HATAKEYAMA, 2010; VANALLE; SALLES, 2011; SALERNO et al. 2001) aiming at reducing inventory and logistics costs and improving service levels. Using JIT concepts, customer and suppliers work in a more cooperative manner, synchronizing the delivery of small lots as a way to minimize the total cost of the supply chain (OMAR et al. 2012). Those benefits added to a reduced distance between customer and supplier (GEBENNINI et al. 2009) induce better practices in the lean logistics.

According to Corrêa and Gianesi (2012), the inventories can provide independence in each step of the production process and JIT has the main objective of eliminating wastes in terms of manufacturing space, in-process inventory and 
INDEPENDENT JOURNAL OF MANAGEMENT \& PRODUCTION (IJM\&P)

http://www.ijmp.jor.br

v. 6, n. 4, October - December 2015

ISSN: 2236-269X

DOI: 10.14807/ijmp.v6i4.341

excessive transportation. Hence, besides reducing costs, JIT contributes to avoid process variations, being not only a tool that provides materials when they are strictly required, but also an optimization technique applied to the production planning and control of products in the customer assembly line (SANTORO; FREIRE, 2008). The inventory levels with JIT utilization are widely employed in the automakers as a way to reduce costs because of small lot sizes, small space dedicated to in-process inventories and reduced reposition cycles, factors that are optimized if proximity between supplier and customer exists (GUARNIERI; HATAKEYAMA, 2010). However, it is relevant to mention that even when the JIT approach is used, it is necessary to recognize that some level of inventory is required to assure production continuity. An adequate management in this area needs to establish the right purchasing and production lot sizes through the balance between the inventory carrying costs and the fixed costs to obtain them (CORREAA; GIANESI, 2012).

Guarnieri and Hatakeyama (2010) state that quality and reliability are prerequisites for the JIT technique, in addition to a good supply chain management aiming at reducing inventory costs. Despite those advantages, the lean logistics is not present in a significant number of tier 1 suppliers in the Brazilian automotive supply chain (MESQUITA; CASTRO, 2008). Corrêa and Gianesi (2012) suggest that the distance between customer and supplier could be a restriction to a wider utilization of JIT. Long distances require large transportation lot sizes to minimize unit transportation costs. As per Lee and Lee (2011), the investment allocated to a new facility is a crucial factor to be considered in the construction of a new plant, taking also into consideration the minimum number of customers to be served and the profitability level of the new facility.

Nevertheless, it is important to point out that in many instances institutional pressures exerted by the customer is a key reason for a new supplier facility to be implemented, since according to Vanalle and Salles( 2011) the supplier location inside or close to the industrial park where the automaker is operating has become an important factor in the customer-supplier relationship. Aymard e Brito (2009) confirm this consideration saying that the customer decision in relation to a given supplier can be made solely because of proximity. Bennett e Klug (2012) reinforce the concept proposing that proximity narrows the trust between the automaker and its suppliers. Tontini e Zanchett (2010) indicate 13 relevant attributes of the logistic 
INDEPENDENT JOURNAL OF MANAGEMENT \& PRODUCTION (IJM\&P)

http://www.ijmp.jor.br

v. 6, n. 4, October - December 2015

ISSN: 2236-269X

DOI: 10.14807/ijmp.v6i4.341

services. Among them, the most important would be delivery reliability, which is also affected by the supplier localization. Gebennin et al. (2009) observed another relevant indicator of geographical distance and logistic efficiency. They identified the correlation between cost reduction and plant relocation as a decisive factor for the maintenance of competitiveness.

Based on this context, this paper aimed at evaluating the details that justify the construction of a new plant dedicated to the manufacture of auto parts in a new location, creating proximity conditions with one of its main customers. To accomplish that a case study was developed considering a national company belonging to tier 1 of the Brazilian automotive industry. Thus, the central research question posed by this study was: Which determinant factors justify the proximity between a customer and one of its suppliers within the Brazilian automotive supply chain?

\section{RESEARCH METHODOLOGY}

To reach the proposed objectives of this paper, this research can be classified as a case study because it investigated questions relating to "how" and "why" and comprised aspects where the boundaries between the phenomenon and its context were not clear (YIN, 2009). To support the case study a company located in the city of Sao Paulo, Brazil, and belonging to the tier 1 of the automotive industry was chosen. This firm is a traditional manufacturer of windshield wipers supplying this component to the main automakers located in the country. It currently employs around 800 employees. It recently implemented a second manufacturing facility about 300 miles far from its original location, but very near its main customer, as a way to create proximity. The financial advantages resulting from this new unity are the central objective of this investigation.

The criteria used to select this company encompassed the availability of data (MARKONI; LAKATOS, 2010) and the utilization of purposeful sampling according to Patton (1990), i.e., selecting a case from which the researcher could extract relevant and significant information for the subject under investigation. To collect the data during the case study the documental research and semi-structured interviews were used as per Marconi and Lakatos (2010) recommendations. The documental information obtained involved sales data, orders generated by EDI, inventory levels and logistic costs. They were acquired through semi-structured interviews performed 
with production managers, product manager, financial manager, logistic coordinator, purchasing coordinator and production planning and control coordinator. To enable a wider understanding of all aspects associated to the central problem under analysis, three managers of the automaker customer were also interviewed: production planning and control, purchasing and production.

\section{CASE STUDY}

The case study was divided in three parts. Initially the cost savings resulting from the inventory reduction allowed by the proximity with customer were evaluated. Then the economies obtained due to the reduced logistic costs were identified. Finally, the additional operating costs of the new facility were determined. Details of each step follow:

\subsection{Inventory Carrying Costs}

To analyze the economic advantages resulting from the inventory reduction obtained by the new and closer to the customer facility, the researchers initially identified how the inventory was managed before the new plant was implemented. For that purpose, a part A with a weekly consumption of 7,500 units was considered. Originally, its production was totally performed in the city of Sao Paulo, 300 miles far from the customer plant, at a rate of 3,000 units per day, with deliveries to the customer every Tuesdays and Thursdays.

It is possible to note that the plant was producing in one week the consumption required for two weeks or 15,000 parts. The remaining days of a given month were dedicated to the manufacture of other product models in the same set of equipment. Furthermore, there was a safety inventory equivalent to one-day production or 3,000 parts. A typical monthly schedule and respective inventory levels are shown in Table 1. The part A supplied to the customer directly from the Sao Paulo plant required an average monthly inventory of 10,300 parts.

According to Corrêa and Gianesi (2012), the traditional way to calculate the inventory carrying cost includes the total storage costs (TSC) which are obtained through the multiplication of the unit inventory maintenance cost for a given period $(\mathrm{mc})$ by the average quantity of inventory (iq) in the same time span: 
$T S C=m_{e} \times t_{q}$

where TSC is the total storage costs, mc is the unit inventory maintenance cost and iq is unit inventory maintenance cost.

Table 1: Monthly schedule and inventory levels before plant relocation - Part A

\begin{tabular}{|c|c|c|c|c|c|c|c|c|c|c|c|c|c|c|c|}
\hline & \multicolumn{15}{|c|}{ First and Second Week } \\
\hline & Sat & Sun & Mon & Tue & Wed & Thu & Fri & Sat & Sun & Mon & Tue & Wed & Thu & Fri & Sat \\
\hline Initial Inventory & 3000 & 3000 & 3000 & 6000 & 4500 & 7500 & 7500 & 10500 & 10500 & 10500 & 13500 & 12000 & 15000 & 15000 & 18000 \\
\hline Production & 0 & 0 & 3000 & 3000 & 3000 & 3000 & 3000 & 0 & 0 & 3000 & 3000 & 3000 & 3000 & 3000 & 0 \\
\hline Delivery & 0 & 0 & 0 & 4500 & 0 & 3000 & 0 & 0 & 0 & 0 & 4500 & 0 & 3000 & 0 & 0 \\
\hline Final Inventory & 3000 & 3000 & 6000 & 4500 & 7500 & 7500 & 10500 & 10500 & 10500 & 13500 & 12000 & 15000 & 15000 & 18000 & 18000 \\
\hline
\end{tabular}

\begin{tabular}{|c|c|c|c|c|c|c|c|c|c|c|c|c|c|c|c|}
\hline & \multicolumn{15}{|c|}{ Third and Fourth Week } \\
\hline & Sat & Sun & Mon & Tue & Wed & Thu & Fri & Sat & Sun & Mon & Tue & Wed & Thu & Fri & Sat \\
\hline Initial Inventory & 18000 & 18000 & 18000 & 18000 & 13500 & 13500 & 10500 & 10500 & 10500 & 10500 & 10500 & 6000 & 6000 & 3000 & 3000 \\
\hline Production & 0 & 0 & 0 & 0 & 0 & 0 & 0 & 0 & 0 & 0 & 0 & 0 & 0 & 0 & 0 \\
\hline Delivery & 0 & 0 & 0 & 4500 & 0 & 3000 & 0 & 0 & 0 & 0 & 4500 & 0 & 3000 & 0 & 0 \\
\hline Final Inventory & 18000 & 18000 & 18000 & 13500 & 13500 & 10500 & 10500 & 10500 & 10500 & 10500 & 6000 & 6000 & 3000 & 3000 & 3000 \\
\hline
\end{tabular}

Source: Researched company.

As part of the evaluation made, it was possible to determine that the unit inventory maintenance cost $\left(m_{c}\right)$ for the chosen part $A$ was $\$ 3.45$ per unit kept in inventory. As the average monthly inventory was 10,300 parts (see Table 1 ), it was possible to calculate the total storage costs (TSC) which reached \$35,535 (\$3.45 x $10,300)$. As the company under study had an opportunity cost of $20 \%$ per year, that average level of inventory represented a $\$ 7,107$ per year of carrying costs.

When the new facility, close to the customer, started its comercial operation, it was possible to implement a significant reduction in inventory levels. The daily production of part A was reduced to 1,500 units, five days per week, four weeks per month. Delivery was scheduled to be made twice per day (morning and evining), confirming what had been stated by Vanalle ans Salles (2011) indicating that most automakers in Brazil were receiving parts and components from suppliers several times a day. One-day production (1,500 parts) was now kept as a safety inventory. This new scheduling and delivery strategy reduced the monthly average inventory to only 1,500 parts as can be seen in Table 2 .

Reproducing the same calculations as above but considering now the production made in the new facility, the total storage costs (TSC) was reduced to $\$$ $5,175(\$ 3.45 \times 1,500)$ and the new average level of inventory represented a $\$ 1,035$ per year of carrying costs, generating total savings of $\$ 6,072$ per year only for that part. 
INDEPENDENT JOURNAL OF MANAGEMENT \& PRODUCTION (IJM\&P)

http://www.ijmp.jor.br

v. 6, n. 4, October - December 2015

ISSN: 2236-269X

DOI: 10.14807/ijmp.v6i4.341

Table 2: Monthly schedule and inventory levels after plant relocation - Part A

\begin{tabular}{lccccccccccccccc} 
& \multicolumn{10}{c}{ First and Second Week } \\
\cline { 2 - 15 } & Sat & Sun & Mon & Tue & Wed & Thu & Fri & Sat & Sun & Mon & Tue & Wed & Thu & Fri & Sat \\
\hline Initial Inventory & 1500 & 1500 & 1500 & 1500 & 1500 & 1500 & 1500 & 1500 & 1500 & 1500 & 1500 & 1500 & 1500 & 1500 & 1500 \\
Production & 0 & 0 & 1500 & 1500 & 1500 & 1500 & 1500 & 0 & 0 & 1500 & 1500 & 1500 & 1500 & 1500 & 0 \\
Delivery & 0 & 0 & 1500 & 1500 & 1500 & 1500 & 1500 & 0 & 0 & 1500 & 1500 & 1500 & 1500 & 1500 & 0 \\
Final Inventory & 1500 & 1500 & 1500 & 1500 & 1500 & 1500 & 1500 & 1500 & 1500 & 1500 & 1500 & 1500 & 1500 & 1500 & 1500 \\
\hline
\end{tabular}

\begin{tabular}{|c|c|c|c|c|c|c|c|c|c|c|c|c|c|c|c|}
\hline & \multicolumn{15}{|c|}{ Third and Fourth Week } \\
\hline & Sat & Sun & Mon & Tue & Wed & Thu & Fri & Sat & Sun & Mon & Tue & Wed & Thu & Fri & Sat \\
\hline Initial Inventory & 1500 & 1500 & 1500 & 1500 & 1500 & 1500 & 1500 & 1500 & 1500 & 1500 & 1500 & 1500 & 1500 & 1500 & 1500 \\
\hline Production & 0 & 0 & 1500 & 1500 & 1500 & 1500 & 1500 & 0 & 0 & 1500 & 1500 & 1500 & 1500 & 1500 & 0 \\
\hline Delivery & 0 & 0 & 1500 & 1500 & 1500 & 1500 & 1500 & 0 & 0 & 1500 & 1500 & 1500 & 1500 & 1500 & 0 \\
\hline Final Inventory & 1500 & 1500 & 1500 & 1500 & 1500 & 1500 & 1500 & 1500 & 1500 & 1500 & 1500 & 1500 & 1500 & 1500 & 1500 \\
\hline
\end{tabular}

Source: Researched company.

\subsection{Transportation Costs}

During the case study, the researchers analyzed another factor that could justify the implementation of a satellite plant to create proximity with customer: transportation costs. Table 3 shows the transportation costs for Part A to move them from the original plant to the customer located 300 miles far.

Table 3: Transportation costs for Part A

\begin{tabular}{|c|c|c|c|c|}
\hline \multicolumn{5}{|c|}{ Transportation costs from original plant to customer - Part A } \\
\hline $\begin{array}{c}\text { Freight cost - Going } \\
(\$ / \text { ton })\end{array}$ & $\begin{array}{l}\text { Weight / trip (ton) } \\
\text { (racks + parts) }\end{array}$ & \$ / Trip & $\begin{array}{l}\text { \# of trips } \\
\text { per month }\end{array}$ & Total \\
\hline$\$ 198.00$ & 4.0 & $\$ 792.00$ & 8 & $\$ 6,336.00$ \\
\hline $\begin{array}{c}\text { Freight cost - Return } \\
\text { (\$/ ton) }\end{array}$ & $\begin{array}{l}\text { Weight / trip (ton) } \\
\text { (racks + parts) }\end{array}$ & \$ / Trip & $\begin{array}{l}\text { \# of trips } \\
\text { per month }\end{array}$ & Total \\
\hline$\$ 162.00$ & 1.0 & $\$ 162.00$ & 8 & $\$ 1,296.00$ \\
\hline \multicolumn{4}{|c|}{ Total transportation cost from the original plant to the customer } & $\$ 7,632.00$ \\
\hline
\end{tabular}

As a result of the implementation of the new plant close to the customer, the transportation costs shown in Table 3 were eliminated because the parts were made at the new facility. However, in the supplying agreement it was established that the customer would provide a milk run service covering $50 \%$ of the needed daily deliveries. The manufacturer should provide the balance. To support that, the supplier made available a small size truck with a driver and an assistant. The truck monthly costs (operation + maintenance + depreciation) to deliver only part $A$ averaged $\$ 1,740.00$. The driver + assistant salaries plus benefits and social costs allocated to that part amounted to $\$ 2,400.00$. As can be seen, the new location generated a total saving of $\$ 3,492.00$ per month $(\$ 7,632.00$ - \$1,740.00 - \$ $2,400.00$ ) or $\$ 41,904.00$ per year only considering part $A$. 
The proximity and the lean logistics supported by the JIT technique aim at reducing manufacturing costs through decrease in inventory levels and transportation charges, as could be verified for part A above. However, it is important to mention that the new facility was producing five different types of parts, all them for the same customer. Based on the production schedules defined for each part it was possible to replicate the same analyses and calculations made for part A for the other four models produced in the new facility. Total cost savings obtained are reported in Table 4.

Table 4. Annual cost savings resulting from new plant location

Annual Cost Savings (\$/Year)

\begin{tabular}{ccccc}
\hline Part & $\begin{array}{c}\text { Annual } \\
\text { Consumption }\end{array}$ & $\begin{array}{c}\text { Inventory } \\
\text { Reduction }\end{array}$ & $\begin{array}{c}\text { Transportaion } \\
\text { Costs }\end{array}$ & Total \\
\hline A & 360,000 & 6,072 & 41,904 & 47,976 \\
B & 336,000 & 5,372 & 41,904 & 47,276 \\
C & 276,000 & 3,619 & 31,428 & 35,047 \\
D & 228,000 & 2,217 & 26,196 & 28,413 \\
E & 324,000 & 5,020 & 36,660 & 41,680 \\
\hline Total & $\mathbf{1 , 5 2 4 , 0 0 0}$ & $\mathbf{2 2 , 3 0 0}$ & $\mathbf{1 7 8 , 0 9 2}$ & $\mathbf{2 0 0 , 3 9 2}$ \\
\hline
\end{tabular}

Source: Researched company.

It is interesting to note that the decline in transportation costs is significantly higher than the savings in terms of inventory reduction, as can be seen in Figure 1. From the $\$ 200$ thousand annual cost savings, almost 90\% came from shipping. Nevertheless, this reduction was somewhat surpassed by the administrative costs required to operate the new facility which indicate that the decision to create proximity with one of its most important customers was not a direct consequence from the cost reductions achieved.

In fact, because of the interviews conducted with some supplier executives, the researchers learned that the decision to relocate part of the manufacturing facilities was primarily made due to strategic reasons, being the cost savings an additional (but not fundamental) reason. This fact reinforces what Salerno et al. (2001) and Vanalle and Salles (2011) stated. Actually, proximity between supplier and its customer is vital to reinforce relationship, allowing the supplier to have preference in terms of volumes, product mix and new developments. 
INDEPENDENT JOURNAL OF MANAGEMENT \& PRODUCTION (IJM\&P)

http://www.ijmp.jor.br

v. 6, n. 4, October - December 2015

ISSN: 2236-269X

DOI: 10.14807/ijmp.v6i4.341

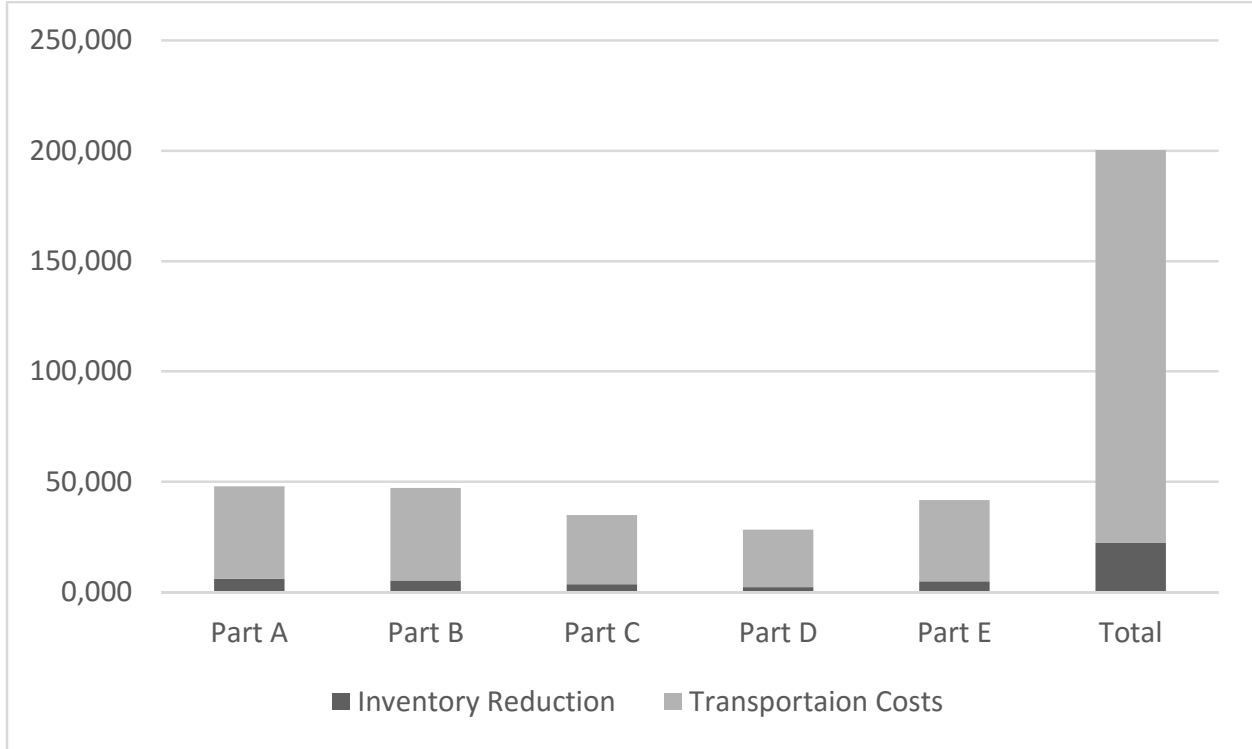

Figure 1: Economies obtained in the new location.

Source: Researched company.

\section{CONCLUSIONS}

Despite generating more than $\$ 200$ thousand annual cost savings resulting from the plant relocation, the case considered in this work has suggested that the real motivation of the supplier to create proximity with one of its most important customers was to straighten the long-term relationship. The actual objective was to generate strategic advantages derived from proximity to better position the supplier to augment its integration and business volumes with its customer. Henceforth, the cost reductions obtained were just upside potentials used to minimize in the shortterm the impact of the additional costs of the new facility and not the primal reason to justify the new location.

The study developed herein generates contributions to both theory and practice. In terms of generation of new knowledge, this paper shows that the longterm competitive advantages resulting from the supplier-customer proximity transcend the conventional reasoning of considering the short-term financial return as the sole viability factor to sustain the decision to build a new plant close to the customer premises. On the practitioner's side, the auto parts company managers can recognize that fact as an opportunity to create strategic gains coming from a closer and reinforced relationship with their key clients.

Finally, it is relevant to mention that this work has some limitations. Firstly, the conclusions established here cannot be generalized because they are supported by 
INDEPENDENT JOURNAL OF MANAGEMENT \& PRODUCTION (IJM\&P)

http://www.ijmp.jor.br

v. 6, n. 4, October - December 2015

ISSN: 2236-269X

DOI: 10.14807/ijmp.v6i4.341

a single case study, considering a manufacturer of a single type of product in the context of the Brazilian auto industry. Hence, it is suggested that additional research be developed expanding the number of auto parts producers, involving different kinds of products and/or components in different countries. Only then, it will be possible to verify if the conclusions established here would have a higher degree of generalization.

\section{REFERENCES}

AYMARD, P.; BRITO, E. (2009) Custos de mudança em serviços logísticos. Gestão e Produção, v.16, n. 3, p. 466-478.

BENNETT, D.; KLUG, F. (2012) Logistics supplier integration in the automotive industry. International Journal of Operations \& Production Management, v. 32, n. 11, p. 1281-1305.

CORREAA, H.L; GIANESI, G.N. (2012) Just in time, MRP II e OPT: um enfoque estratégico. São Paulo: Atlas.

GEBENNINI, E.; GAMBERINI, Y.; MANZINI, R. (2009) An integrated productiondistribution model for the dynamic location and allocation problem with safety stock optimization. International Journal Production Economics, v. 122, p. 286-304.

GUARNIERI, P.; HATAKEYAMA, K. (2010) Formalização da logística de suprimentos: caso das montadoras e fornecedores da indústria automotiva brasileira. Produção, v. 20, n. 2, p. 186-199.

LEE, J.; LEE, Y. (2012) Facility location and scale decision problem with customer preference. Computers \& Industrial Engineering, v. 63, p. 184-191.

MARCONI, M.A.; LAKATOS, E.M. (2010). Fundamentos de metodologia científica, $7^{\text {th }}$ ed. São Paulo: Atlas.

MESQUITA, M.; CASTRO, R. (2008) Análise das práticas de planejamento e controle da produção em fornecedores da cadeia automotiva brasileira. Gestão e Produção, v. 15, n. 1, p. 33-42.

OMAR, M.; SARKER, R; OTHMAN, W.. 2012. A just in time three level integrated manufacturing system for linearly time varying demand process. Applied

Mathematical Modelling, v. 37, p. 1275-1281.

PACHECO, D.; JUNIOR,A.; ROCHA, E.; DORNELLES, P. (2012) Uma investigação sobre as implicações da logística enxuta: uma análise das percepções de clientes e fornecedores. In: ENEGEP - ENCONTRO NACIONAL DE ENGENHARIA DE PRODUÇÃO, 32, Bento Gonçalves, Proceedings... Rio de Janeiro: ABEPRO, 2012.

PATTON, M.Q. 1990. Qualitative evaluation and research methods. Newbury Park, CA: Sage.

REGO, J.; MESQUITA, M. (2011) Controle de estoque de peças de reposição: uma revisão da literatura. Produção, v. 21, n. 4, p. 645-655. 
SALERMO, M.S. et al. (2001) Mapeamento da nova configuração da cadeia automotiva brasileira. Departamento de Engenharia de Produção da Escola Politécnica da Universidade de São Paulo. São Paulo: EDUSP.

SANTORO, M.; FREIRE, G. (2008) Análise comparativa entre modelos de estoques. Produção, v. 18, n. 1, p. 89-98.

TONTINI, G.; ZANCHETT, R. (2010) Atributos de satisfação e lealdade em serviços logísticos. Gestão e Produção, v. 17, n. 4, p. 801-816.

VANALLE, R.M.; SALLES, J.A.A. (2011) Relação entre montadoras e fornecedores: modelos teóricos e estudos de caso na indústria automobilística brasileira. Gestão e Produção, v. 18, n. 2, p. 237-250.

YIN, R.K. 2009. Case study research: design and methods, $4^{\text {th }}$ ed. Newbury Park, CA: Sage. 